\title{
Profiling of rumen fermentation, microbial population and digestibility in goats fed with dietary oils containing different fatty acids
}

\author{
I. Nur Atikah', A. R. Alimon², H. Yaakub², N. Abdullah', M. F. Jahromi', M. Ivan ${ }^{1}$ and A. A. Samsudin² (D
}

\begin{abstract}
Background: The effects of the dietary oils with differing fatty acid profiles on rumen fermentation, microbial population, and digestibility in goats were investigated. In Experiment I, rumen microbial population and fermentation profiles were evaluated on 16 fistulated male goats that were randomly assigned to four treatment groups: i) control (CNT), ii) olive oil (OL), iii) palm olein oil (PO), and iv) sunflower oil (SF). In Experiment II, another group of 16 male goats was randomly assigned to the same dietary treatments for digestibility determination.

Results: Rumen ammonia concentration was higher in CNT group compared to treatment groups receiving dietary oils. The total VFA and acetate concentration were higher in SF and OL groups, which showed that they were significantly affected by the dietary treatments. There were no differences in total microbial population. However, fibre degrading bacteria populations were affected by the interaction between treatment and day of sampling. Significant differences were observed in apparent digestibility of crude protein and ether extract of treatment groups containing dietary oils compared to the control group.

Conclusions: This study demonstrated that supplementation of different dietary oils containing different fatty acid profiles improved rumen fermentation by reducing ammonia concentration and increasing total VFA concentration, altering fibre degrading bacteria population, and improving apparent digestibility of crude protein and ether extract.
\end{abstract}

Keywords: Dietary oil, Digestibility, Goat, Rumen fermentation, Rumen microbial population

\section{Background}

Ruminant acquires energy from plant materials through the activity of microbial fermentation and plant degradation mainly by groups of cellulolytic bacteria. The dynamics of major cellulolytic bacterial population found in the rumen, in particular Fibrobacter succinogens, Ruminococcus albus, and Ruminococcus flavefaciens, have been widely studied in response to dietary shift [1] or between species [2] using molecular approaches of quantitative real-time polymerase chain reaction (qPCR). The importance of cellulolytic bacteria in ruminant nutrition is due to the fact that this particular group of bacteria plays a critical role not only in

\footnotetext{
* Correspondence: anjas@upm.edu.my

${ }^{2}$ Department of Animal Science, Faculty of Agriculture, Universiti Putra

Malaysia, UPM, 43400 Serdang, Selangor, Malaysia

Full list of author information is available at the end of the article
}

utilizing feeds that are not suitable for monogastric animals, but also in facilitating animals to survive on poor quality fibrous forages [3]. During the fermentation process, energy is released in the form of adenosine triphosphate (ATP), which is used to fuel different activities of rumen microorganism. This energy can be improved in ruminant by supplementing the animals with dietary fat, an approach that has been commonly practiced.

Other studies have shown different effects of vegetable oil supplementations in rumen fermentation and microbial population using cattle. For example, [4] reported that supplementation of linseed oil to dairy cow did not affect ruminal $\mathrm{pH}$, ammonia, and total volatile FA concentrations. Similarly, [5] reported that flaxseed supplementation to calves has no effects on rumen fermentation parameters. However, fish oil supplementation in steer ruminal

(c) The Author(s). 2018 Open Access This article is distributed under the terms of the Creative Commons Attribution 4.0 International License (http://creativecommons.org/licenses/by/4.0/), which permits unrestricted use, distribution, and reproduction in any medium, provided you give appropriate credit to the original author(s) and the source, provide a link to the Creative Commons license, and indicate if changes were made. The Creative Commons Public Domain Dedication waiver (http://creativecommons.org/publicdomain/zero/1.0/) applies to the data made available in this article, unless otherwise stated. 
fluid had lower ruminal acetate and butyrate but greater propionate concentration, as reported by [6]. Another study from [7] reported that feeding oilseeds from flaxseed to cows had no effects on $\mathrm{pH}$ and concentrations of $\mathrm{NH}_{3}-\mathrm{N}$ and total volatile fatty acids while acetate: propionate ratio was decreased. In the same study, they also described that oilseeds decreased protozoa and increased total cellulolytic bacteria population in rumen fluid. Similarly, [8] showed that supplementation with palm oil in cows reduced protozoa population, but it did not affect cellulolytic bacteria population in cows. Other vegetable oils such as coconut oil [9] and soybean oil [10] are used as energy sources and have the potential to manipulate the microbial ecosystem of the rumen to enhance fibrous feed digestibility, reduce methane emission, and reduce nitrogen excretion by ruminants [11].

There is not much information available that emphasizes the effect of diets supplemented with olive oil that contains oleic acid (C18:1), sunflower oil that contains linoleic acid (C18:2), and palm olein oil that consists of linoleic acid (C18:2) and palmitic acid (C16:0) on rumen fermentation, rumen microbial populations, and digestibility in goats. Therefore, the aim of this study was to investigate rumen microbial population, fermentation profile and nutrient digestibility for local goats fed diets supplemented with sunflower oil (SF), olive oil (OL), or palm olein oil $(\mathrm{PO})$.

\section{Results}

\section{Rumen $\mathrm{pH}$ and volatile fatty acids}

The results of ruminal $\mathrm{pH}$ and VFA concentration are presented in Table 1 . The mean of ruminal $\mathrm{pH}$ ranged between $6.26(\mathrm{PO})$ and $6.80(\mathrm{OL})$ and was affected by day of sampling $(P<0.01)$. Different treatment diets had no significant effect on ruminal $\mathrm{pH}$. However, OL fed group tended to have a slightly higher rumen $\mathrm{pH}$ value than that of the other groups.

The total VFA concentration (mmol) was significantly higher $(P<0.05)$ in OL and SF compared to the CNT and PO groups (Table 1). The OL and SF groups had higher $(P<0.05)$ concentration of acetic acid compared to the other groups. Diets supplemented with PO did not show significant differences in acetate when compared to the control group. Supplementation of OL showed an increased level of isobutyric acid concentration when compared to other treatment groups. Propionate, butyrate, valerate, and isovalerate concentrations and acetic acid to propionic acid ratio (A/P) were not affected by the different types of oil supplementation. However, the significant effect of sampling day can be observed in the concentrations of the total VFA, acetate, butyrate, and valerate.

\section{Ammonia}

The mean values of ruminal ammonia are presented in Table 1. Addition of dietary oils significantly decreased the concentration of ruminal ammonia. The concentration ( $\mathrm{mg} / \mathrm{l})$ of ammonia-N in the rumen fluid was significantly affected by diet $(P<0.05)$, day of sampling $(P<0.01)$, and diet $\times$ day of sampling interaction $(P<0.05)$. Higher amount of ammonia concentration was observed in CNT (42.6 mg/l) compared to other groups (36.4-37.9 mg/l).

\section{Microbial population}

The effects of dietary oils on rumen microbial population are presented in Table 2. Higher numbers of total bacteria could be observed in the treatment groups compared to CNT although not statistically significant $(P>0.05)$. No significant difference was observed in the $F$. succinogenes, $R$. albus, and $R$. flavefaciens populations although the highest level of $\log 10$ copy no./g was recorded in SF

Table 1 Rumen fermentation parameters (mean \pm SE) of goats fed diet supplemented with different types of oils

\begin{tabular}{|c|c|c|c|c|c|c|c|}
\hline \multirow[t]{2}{*}{ Parameters } & \multicolumn{4}{|l|}{$\underline{\text { Treatment }}$} & \multicolumn{3}{|c|}{$P$-value } \\
\hline & CNT & $\mathrm{OL}$ & $\mathrm{PO}$ & SF & $\operatorname{Tr}$ & Day & $\operatorname{Tr} \times$ Day \\
\hline $\mathrm{pH}$ & $6.29 \pm 0.11$ & $6.80 \pm 0.11$ & $6.26 \pm 0.06$ & $6.33 \pm 0.07$ & NS & $* *$ & NS \\
\hline Ammonia (mg/l) & $42.6 \pm 1.65^{a}$ & $37.9 \pm 1.36^{b}$ & $36.4 \pm 1.08^{b}$ & $36.9 \pm 1.24^{b}$ & $* *$ & * & * \\
\hline Total VFA (mmol) & $89.42 \pm 8.59^{b}$ & $95.58 \pm 7.81^{a}$ & $91.11 \pm 6.44^{b}$ & $95.79 \pm 3.15^{a}$ & $*$ & $*$ & NS \\
\hline Acetate (\%) & $59.22 \pm 5.83^{b}$ & $63.70 \pm 5.46^{a}$ & $56.793 .56^{b}$ & $63.72 \pm 2.01^{a}$ & $*$ & $*$ & $*$ \\
\hline Propionate (\%) & $18.21 \pm 2.11$ & $19.62 \pm 1.47$ & $22.15 \pm 2.81$ & $20.22 \pm 0.95$ & NS & NS & NS \\
\hline Butyrate (\%) & $8.19 \pm 0.89$ & $8.83 \pm 0.99$ & $8.13 \pm 0.96$ & $8.37 \pm 0.71$ & NS & $*$ & NS \\
\hline Isobutyrate (\%) & $0.76 \pm 0.13^{b}$ & $0.88 \pm 0.11^{a}$ & $0.73 \pm 0.04^{b}$ & $0.68 \pm 0.04^{b}$ & * & NS & NS \\
\hline Valerate (\%) & $2.18 \pm 0.48$ & $2.42 \pm 0.13$ & $2.14 \pm 0.24$ & $1.72 \pm 0.28$ & NS & $*$ & $*$ \\
\hline Isovalerate (\%) & $0.86 \pm 0.25$ & $1.13 \pm 0.13$ & $1.17 \pm 0.14$ & $1.08 \pm 0.16$ & NS & NS & NS \\
\hline Acetate/Propionate & $3.25 \pm 0.18$ & $3.72 \pm 0.22$ & $2.56 \pm 0.30$ & $3.15 \pm 0.19$ & NS & NS & NS \\
\hline
\end{tabular}

CNT Control diet, OL Olive oil diet, $P O$ Palm olein diet, SF Sunflower oil diet, $\operatorname{Tr}$ Treatment

"Significant level at $P<0.05 ;{ }^{* *}$ Significant level at $P<0.01$

${ }^{a},{ }^{b}$ Means in the same row with different superscripts are statistically different $(P<0.05)$ 
Table 2 Effects of supplementation with different types of oils on microbial population (mean \pm SE) in the rumen of goats

\begin{tabular}{|c|c|c|c|c|c|c|c|}
\hline \multirow[t]{2}{*}{ Parameter } & \multicolumn{4}{|l|}{ Treatment } & \multicolumn{3}{|l|}{$P$-value } \\
\hline & CNT & $\mathrm{OL}$ & $\mathrm{PO}$ & SF & Treatment & Day & Treatment×Day \\
\hline Total Microbes (Log10 copy No/g) & $9.56 \pm 0.21$ & $10.20 \pm 0.15$ & $10.01 \pm 0.13$ & $9.83 \pm 0.16$ & NS & NS & NS \\
\hline Fibrobacter succinogenes (Log10 copy No/g) & $4.20 \pm 0.18$ & $3.67 \pm 0.18$ & $4.20 \pm 0.14$ & $4.21 \pm 0.14$ & NS & * & * \\
\hline Rumonococcus albus (Log10 copy No/g) & $7.81 \pm 0.21$ & $7.65 \pm 0.18$ & $7.95 \pm 0.22$ & $8.07 \pm 0.19$ & NS & * & * \\
\hline Ruminococcus flavefaciens (Log10 copy No/g) & $5.02 \pm 0.19$ & $5.06 \pm 0.26$ & $5.32 \pm 0.20$ & $5.36 \pm 0.10$ & NS & * & * \\
\hline Methanogenic archea (Log10 copy No/g) & $3.60 \pm 0.12^{b}$ & $4.23 \pm 0.22^{\mathrm{a}}$ & $3.91 \pm 0.14^{\mathrm{ab}}$ & $4.39 \pm 0.21^{\mathrm{a}}$ & * & * & * \\
\hline Protozoa (Log10 copy No/g) & $3.30 \pm 0.22$ & $2.63 \pm 0.22$ & $3.30 \pm 0.13$ & $3.22 \pm 0.15$ & NS & * & NS \\
\hline
\end{tabular}

CNT Control diet, OL Olive oil diet, PO Palm olein diet, SF Sunflower oil diet, $\operatorname{Tr}$ Treatment

*Significant level at $P<0.05$

a, b Means \pm std. error in the same row with different superscripts are statistically different $(P<0.05)$

groups. Significant differences $(P<0.05)$ were observed for methanogenic archea population, and the numbers were influenced by treatment, day of sampling, and the interaction of treatment $\times$ day. Population of protozoa demonstrated that there were no significant differences among all the treatment groups although the $\mathrm{CNT}$ and $\mathrm{PO}$ groups had higher values of $\log 10$ copy no./g and were significantly affected by day of sampling $(P<0.05)$. As shown in Table 2, significant differences are seen in the methanogens population while the protozoa population is not significantly affected by the treatment diets.

\section{Apparent digestibility}

The results of apparent digestibility study are presented in Table 3. The DM, OM, NDF, and ADF also followed a similar pattern with the treatment group $(P>0.05)$. The CP apparent digestibility was significantly improved $(P<0.05)$ in all treatment groups containing oil, in which OL had the highest $\mathrm{CP}$ apparent digestibility (85.04\%). The apparent digestibility of EE also followed a similar pattern where the three treatments of OL, PO, and SF had a higher EE digestibility $(P<0.05)$ compared to $\mathrm{CNT}$, with SF groups having the highest apparent digestibility percentage (91.13\%). However, no significant difference was observed in fibre digestibility although the PO and SF groups numerically tended to have higher ADF digestibility.

\section{Discussion}

\section{Rumen $\mathrm{pH}$ and volatile fatty acids}

Ruminal $\mathrm{pH}$ values were within normal range, and the increment has minimal effects on rumen cellulolytic processes of fibre and protein digestion (6.0-7.0) [12]. This result suggests that the microbial population of rumen is able to adapt to the diet given, regardless of the additions and differences in composition of dietary oil supplemented [13]. Adequate roughage supply in the diet reduced the negative effect of dietary oil on rumen fermentation because the fibre fraction creates a supporting environment for rumen microbes to hydrolyze the dietary oils $[6,14,15]$. The findings of the present study are consistent with those of [8] who reported that supplementation of palm oil did not give negative effects on ruminal $\mathrm{pH}$ in dairy cows. In addition, other studies using different types of dietary oils in other ruminants have also reported similar observations [16-18].

The increased level of the total VFA concentration in OL and SF groups in the present study indicates the efficiency of nutrient digestion. It confirms the fact that the notable effect of supplementing dietary oils on rumen fermentation depends on the type and level of fatty acids [10]. A similar result was reported by [19], where supplementation of $\mathrm{C}_{18}$ fatty acid increased the total VFA concentration although less influence was seen in the different types of fatty acid supplemented. Nevertheless,

Table 3 Apparent digestibility (\% DM) of nutrient (mean \pm SE) in goats fed diet supplemented with different types of oils

\begin{tabular}{|c|c|c|c|c|c|}
\hline \multirow{2}{*}{$\begin{array}{l}\text { Apparent } \\
\text { digestibility } \\
(\%)\end{array}$} & \multicolumn{4}{|l|}{ Treatment } & \multirow[t]{2}{*}{$P$-value } \\
\hline & CNT & $\mathrm{OL}$ & PO & SF & \\
\hline Dry matter & $75.81 \pm 2.77$ & $73.49 \pm 1.98$ & $75.44 \pm 1.09$ & $75.37 \pm 1.57$ & NS \\
\hline Organic matter & $80.05 \pm 1.78$ & $80.84 \pm 1.57$ & $80.17 \pm 1.61$ & $78.81 \pm 2.34$ & NS \\
\hline Crude protein & $77.65 \pm 0.81^{b}$ & $85.04 \pm 1.19^{a}$ & $82.20 \pm 2.27^{\mathrm{a}}$ & $82.43 \pm 1.44^{a}$ & * \\
\hline Ether extract & $59.89 \pm 10.39^{b}$ & $88.11 \pm 1.46^{\mathrm{a}}$ & $87.92 \pm 1.93^{\mathrm{a}}$ & $91.13 \pm 2.76^{a}$ & * \\
\hline NDF & $75.19 \pm 4.31$ & $71.59 \pm 2.84$ & $71.82 \pm 3.47$ & $71.28 \pm 4.31$ & NS \\
\hline ADF & $47.42 \pm 1.99^{b}$ & $54.75 \pm 5.27^{\mathrm{a}}$ & $57.54 \pm 4.49^{a}$ & $55.01 \pm 4.41^{a}$ & * \\
\hline
\end{tabular}

CNT Control diet, OL Olive oil diet, PO Palm olein diet, SF Sunflower oil diet

${ }^{a}$, Means in the same row with different superscripts are statistically different $(P<0.05)$ 
different responses were observed in the work done by [20] that showed the reduction in the concentration of VFA supplemented with fatty acids.

A significant increase $(P<0.05)$ in the acetate level in the OL and SF can also suggest a modification of the ruminal microbial population [19, 21]. However, the validation on this reason needs to be done in future studies. This result is thought to be due to the modification of the ruminal microbial ecosystem, as occurs with 18-carbon polyunsaturated FA. A decrease in cellulolytic and methanogenic bacteria is observed with most fat sources inclusion. For branched fatty acid concentration, there was a significant increment in the molar proportion of isobutyrate in the OL group. The finding is consistent with a study done by [20] who reported that branched fatty acid concentration was increased with the supplementation of fatty acid.

\section{Ammonia}

Fat supplementation in ruminant diets has been shown to consistently depress rumen ammonia concentration $[22,23]$. In the current study, the ammonia level recorded in the oil supplemented groups was within the normal range as reported by [24]. The optimum ammonia level that favors the ruminal microbial activity in animals fed with lignocellulosic materials was between 16.5 and $37.9 \mathrm{mg} / \mathrm{l}$. There were also significant differences observed by the interaction of treatments with day of sampling, suggesting that ammonia level in rumen might be associated with the shift of the microbial population of rumen by time, due to the addition of dietary oils. A report by [25] suggested that the increase in the ammonia level was due to the reduction in protozoal predation toward rumen bacteria thus, reducing the recycling of bacteria protein in the rumen. A similar result by [26] also reported that ammonia concentration tended to increase when the longer chain of unsaturated fatty acid was present in the diet. [27] reported that rumen ammonia concentration reduction corresponded with lowered ammonia flow to the duodenum and was similar to other studies $[28,29]$ in sheep as well as in cattle $[18$, 22]. However, contradictory results with regard to ammonia level in previous studies on ruminant have been noted with supplementations of linoleic acid by $[19,30]$ and supplementations of sunflower oil in cattle by [31].

\section{Microbial population}

Supplementation of vegetables oils did not alter the fibre degrading bacteria and total microbial populations in the present study, indicating that these microorganisms are not sensitive to dietary oils supplementation [32]. Another possible reason was mentioned by [33] who reported that the negative effects toward ruminal fibrolytic bacteria were neglected in the case of high grain-fed diet. In their study, neither NDF nor fibrolytic bacteria population has shown significant responses toward fatty acid supplementation. Vegetable oil supplementations have shown inconsistent results of rumen microbial population in other studies. [6] observed a decrease of $F$. succinogenes population but not the $R$. albus, and $R$. flavefaciens populations in steers. Furthermore, [10] reported a decrease of $F$. succinogenes and $R$. flavefaciens population. In addition, [34] observed an increase of $F$. succinogenes, $R$. albus, and $R$. flavefaciens populations in goats. [32] on the other hand, observed no effects on $F$. succinogenes population and a decrease of $R$. albus and $R$. flavefaciens populations in goats. The significant differences observed by sampling day and interaction of treatments with sampling day on fibre degrading bacteria, methanogens, and protozoa populations in the present study suggest that the ruminal microbial populations shifted by time due to the addition of dietary oils.

The population of protozoa in rumen often correlates to the population of methanogens. It has been reported that a reduction in protozoa reduced the methanogens population since methanogens live in association with protozoa, linked by hydrogen transfer within the interspecies [35]. However, the association of those methanogens is only $0.1-0.2 \%$ of the total population, whereby the others that exist freely in the rumen might not be affected by the supplementation to the same extent. Due to that, the reduction of methanogens does not always follow the population pattern similar to protozoa. A decrease in rumen protozoa population was observed with the supplementation of blended canola and palm oil by [34] and supplementation of linseed oil and coconut oil by [36]. A similar observation was also reported by [10] who observed that dietary soybean oil reduced the population of methanogens in lambs.

\section{Apparent digestibility}

An increase in $\mathrm{CP}$ digestibility in the treatment groups suggests that oil supplementation can act as a source of energy for rumen microbes to convert feed protein into microbial protein, which is more digestible. Besides, the increased CP digestibility may be due to the reduction in the microbial degradation by protozoa, which in turn increased the level of protein available in the lower sections of the gastrointestinal tract [37].

The higher apparent digestibility of EE in the treatment groups reported in this study is in agreement with a study using lambs by [38]. Diet rich in dietary fats tends to have a higher hydrolysis percentage in the rumen compared to the conventional diet [39]. Lipases that are involved in rumen lipid hydrolysis have been shown to be more active in diets with high fibre and protein contents [40]. A previous study by [15] showed that fatty acid had higher digestibility with increasing number of double bonds. In this 
study, although there were no significant changes, the SF group showed higher values in EE digestibility. It may be due to the presence of linoleic acid (C18:2) in sunflower oil compared to the presence of oleic acid (C18:1) in both olive oil and palm olein.

Supplementation of dietary oils tended to coat the particle of fibre, thus preventing them from the attack of rumen microbes [41]. In the present study, although there was a decreased pattern of NDF digestibility, there were no significant differences observed. This may suggest that the level of oil inclusion is not enough to deliver the effect. This result is also supported by [42] who indicated that fibre digestion would be limited when fat content in ruminant diet is higher than $70 \mathrm{~g} / \mathrm{kg} \mathrm{DM}$ intake, a level which is higher than the level used in the present study. Another reason is that NDF digestibility follows ruminal protozoa population, as supported in a study by [43]. Similar results by [44] did not find variations in NDF digestibility whereas ADF digestibility was higher in in vitro study. The increase in nutrient digestibility observed in the present study might have been caused by the increase in ruminal retention time as suggested by $[45,46]$.

\section{Conclusion}

Supplementation with olive oil, palm olein oil, and sunflower oil improved and developed better ruminal microorganism population to a certain extent in goats. In terms of digestibility, oil supplementation improved both protein and fat digestibility. For future research, it is recommended that studies on the effects of $\mathrm{C}_{18}$ fatty acids on the metabolic activity of microbial population in rumen, particularly methanogens, be deeply clarified, including determination of the long-term effects of fatty acids on in vivo rumen fermentation, methanogenesis, and animal performance. With regard to rumen physiology, understanding the association, symbiotic relationship, and cross feeding among microorganism is important in predicting the response of microorganisms when given a new diet.

\section{Methods}

\section{Animals and diet}

The experiment was carried out at Department of Animal Science, Faculty of Agriculture, Universiti Putra Malaysia following the guidelines approved by the Institutional Animal Care and Use Committee (IACUC) (Approval No. R064/2016) of the Universiti Putra Malaysia. Sixteen mature local Katjang-crossed male goats aged between 20 and 24 months with an average weight of $28.32 \pm 1.85 \mathrm{~kg}$ and fitted with rumen cannula were used for rumen fermentation profile and microbial population study (Experiment I). The animals were properly maintained by treated against endo and ectoparasites prior to the commencement of the experimental procedure. In addition, all of the animals were under supervisory of veterinarian for assessing their health. In another study (Experiment II), 16 Katjang-crossed male goats aged between 10 and 12 months with an average weight of $23.17 \pm 0.94 \mathrm{~kg}$ were used to determine the digestibility of nutrients in the diets. The diets were formulated to have approximately equal amount of crude protein $(\mathrm{CP})$ and energy content [47]. All of the animals used in these two studies were purchased from a commercial farm, De Kebun Enterprise in Selangor.

The animals were randomly assigned into four groups to receive four different dietary treatments: i) basal diet (CNT or control), ii) basal diet + olive oil (OL), iii) basal diet + palm olein oil (PO), and iv) basal diet + sunflower oil (SF). The oil content was supplemented at the rate of $6 \%$ of the total feed ingredients. The oil content was supplemented at the rate of $6 \%$ of the total feed ingredients. The ingredients, including the oils, were purchased from commercial sources. Dry matter (DM), organic matter $(\mathrm{OM})$, crude protein $(\mathrm{CP})$, neutral detergent fibre (NDF), and acid detergent fibre (ADF) of the experimental diets were analyzed according to [48, 49]. The ingredients and chemical composition of the diets are presented in Table 4.

\section{Animal housing and management}

The experiments were conducted in Serdang, Selangor, Malaysia ( $3^{\circ} 2^{\prime} 0^{\prime \prime}$ North, $101^{\circ} 43^{\prime} 0^{\prime \prime}$ East). The cannulated animals were kept individually in separate pens while in the digestibility study, the animals were kept in an individual metabolic crate and had free access to water.

\section{Experimental procedure and sampling schedule}

Experiment I was conducted for 28 days of adjustment period followed by 30 days of treatment period. During the adjustment period, all the animals were fed with basal diet that acted as the control diet. The diet was offered ad libitum to the goats at 09:00 daily. After the adjustment period, the animals were randomly assigned according to a completely randomized design into four groups, with each group consisted of four goats and received one of the four dietary treatments. The random selection was done in Microsoft Excel using tag number of animals. Rumen content was collected on days 27 and 28 of the adjustment period, which is considered as the initial sampling day. The data were pooled and recorded as day 0 of the experimental period. Rumen samples were collected from different parts of the rumen $2 \mathrm{~h}$ after morning feeding through the cannula. Similarly, rumen samples were also collected on day $2,4,6,12,18$, 24 , and 30 of treatment period. 
Table 4 Ingredients and chemical composition of treatment diets

\begin{tabular}{|c|c|c|c|c|}
\hline & \multicolumn{4}{|c|}{ Treatments } \\
\hline & CNT & $\mathrm{OL}$ & $\mathrm{PO}$ & SF \\
\hline \multicolumn{5}{|l|}{ Ingredient (as fed) } \\
\hline Rice straw & 30.8 & 25.8 & 25.8 & 25.8 \\
\hline Barley grain & 35.0 & 35.0 & 35.0 & 35.0 \\
\hline Soybean meal & 30.0 & 30.0 & 30.0 & 30.0 \\
\hline Molases & 2.0 & 1.0 & 1.0 & 1.0 \\
\hline Vitamin mineral-mix & 0.5 & 0.5 & 0.5 & 0.5 \\
\hline Limestone & 1.3 & 1.3 & 1.3 & 1.3 \\
\hline Sodium Sulphate & 0.4 & 0.4 & 0.4 & 0.4 \\
\hline Olive oil & - & 6.0 & - & - \\
\hline Palm Oil & - & - & 6.0 & - \\
\hline Sunflower oil & - & - & - & 6.0 \\
\hline \multicolumn{5}{|l|}{ Chemical analysis (DM \%) } \\
\hline DM & 76.17 & 76.02 & 78.27 & 78.73 \\
\hline $\mathrm{OM}$ & 93.60 & 93.34 & 94.61 & 94.96 \\
\hline $\mathrm{CP}$ & 15.76 & 15.48 & 15.9 & 16.00 \\
\hline $\mathrm{EE}$ & 1.86 & 4.56 & 4.70 & 4.74 \\
\hline NDF & 63.53 & 58.76 & 58.54 & 51.27 \\
\hline ADF & 17.04 & 18.26 & 20.66 & 21.41 \\
\hline \multicolumn{5}{|c|}{ Fatty acid (g/100 g total fatty acid DM) } \\
\hline$C-16: 0$ & 8.09 & 11.72 & 44.50 & 4.92 \\
\hline$C-18: 0$ & 2.70 & 1.40 & 3.73 & 6.28 \\
\hline$C-18: 1, n 9$ & 27.88 & 73.20 & 41.45 & 28.47 \\
\hline$C-18: 2, n 6$ & 55.76 & 12.9 & 9.62 & 59.36 \\
\hline$C-18: 3, \cap 3$ & 5.57 & 0.80 & 0.30 & 0.97 \\
\hline
\end{tabular}

CNT Control diet, OL Olive oil diet, PO Palm olein diet, SF Sunflower oil diet, $D M$ Dry matter, $O M$ Organic matter, $C P$ Crude protein, EE Ether extract, NDF Neutral detergent fiber, ADF Acid detergent fiber, C-16:0 Palmitic acid, C-18:0 Stearic acid, C-18:1, $n 9$ Oleic acid, C-18:2, $n 6$ Linoleic acid, C-18:3, $n 3$ Linolenic acid

Determination of rumen microbial population was done on the rumen content collected on day 0,12 , and 30 using real-time PCR. Briefly, about $500 \mathrm{ml}$ of rumen fluid was collected. Rumen $\mathrm{pH}$ was immediately measured and then divided into two portions. The first portion of rumen fluid collected was squeezed through four layers of cheesecloth to eliminate larger solid feed particles. Immediately, two drops of sulphuric acid were added to stop further fermentation. The samples were then kept at $20{ }^{\circ} \mathrm{C}$ until they were further processed for VFA and ammonia determination. The second portion of the rumen fluid was immediately kept in ice and stored at $-20{ }^{\circ} \mathrm{C}$ until further analyses of microbial population study using a qPCR procedure.

For Experiment II, all animals were placed in an individual metabolic crate throughout the 19 days of the experiment (14 days of adjustment period to experimental diets and 5 days of sampling). The goats were divided into four groups of four goats and fed with the respective diets. They had free access to clean water. The respective diets were offered ad libitum to the goats at 09:00 daily until day 14. The feed intake of each animal on days 11-14 was recorded. On days 15-19, the animals were fed with $90 \%$ of the recorded intake. Fecal samples were collected daily from day 15 until day 19 , and approximately $10 \%$ of the total collections were kept frozen at $-20{ }^{\circ} \mathrm{C}$ until further chemical analyses of nutrients. At the end of this study, all goats were fasted for $12 \mathrm{~h}$ with free access to drinking water, transported to the abattoir, allowed to rest, and then weighed before slaughter. The goats were slaughtered in accordance with the procedures outlined in MS1500:2009 (Department of Standards Malaysia, 2009) which allows animal to be slaughtered, without being stunned, with a razor sharp knife. In this study the slaughter was performed by a certified and highly experienced technician with a sharp knife. The goats were to be used for another study to determine the effects of different oils on carcass and meat quality which involves a food tasting study (not reported in the current study) [50].

\section{Chemical analyses of feed and fecal samples}

Feed and fecal samples were analyzed for DM, OM, CP, and EE using the procedure by [48], whereas NDF and $\mathrm{ADF}$ were determined using the procedure by [49].

\section{Rumen $\mathrm{pH}$ and volatile fatty acid determination}

The $\mathrm{pH}$ of the rumen content was measured immediately after the collection of the rumen fluid using a portable $\mathrm{pH}$ meter (Eco Testr $\mathrm{pH}$ 1, Eutech Instruments). For VFA determination, rumen filtrated samples were thawed at $4{ }^{\circ} \mathrm{C}$ prior to analysis following the procedure described by [51] with some modifications. One $\mathrm{ml}$ $3: 1 \mathrm{v} / \mathrm{v}$ solution of $24 \%$ metaphosphoric acid and $5 \%$ formic acid was added into $5 \mathrm{ml}$ of the rumen filtrate. The mixture was left to stand for $30 \mathrm{~min}$ before being centrifuged at $12,000 \mathrm{x} \mathrm{g}$ for $20 \mathrm{~min}$. Then $0.5 \mathrm{ml}$ of supernatant was collected and kept in $2-\mathrm{ml}$ vials, and $0.5 \mathrm{ml}$ internal standard (4-methyl-n-valeric acid) was pipetted into the vials. The samples were analyzed using gas chromatography, equipped with Flame Ionization Detector (FID) and capillary column (DB-FFAP, 122-3232).

\section{Ammonia determination}

Rumen filtrated samples were centrifuged at $12,000 \mathrm{x} \mathrm{g}$ for $20 \mathrm{~min} .5 \mathrm{ml}$ of supernatant was collected and kept for further determination of the ammonia content using a protocol described by [52]. A standard solution was prepared using $1.908 \mathrm{~g}$ of ammonium chloride dissolved in $500 \mathrm{ml}$ distilled water to give $1000 \mathrm{mg} / \mathrm{l} \mathrm{ammonia-} \mathrm{ni-}$ trogen (ammonia-N). A standard 0.2, 0.5, 1.0, and 
$2.0 \mathrm{ppm}$ solution were prepared by dissolving $0.02,0.05$, 0.10 , and $0.20 \mathrm{ml}$ of the stock solution with $100 \mathrm{ml}$ distilled water, respectively. $5 \mathrm{ml}$ of water (blank) or standard was added in an Erlenmeyer flask, and $0.2 \mathrm{ml}$ of the phenol solution was added and swirled. In sequence, $0.2 \mathrm{ml}$ of nitroprusside and $0.5 \mathrm{ml}$ of oxidizing solution were added. The flask was then swirled, stopped and allowed to stand for $1 \mathrm{~h}$ at room temperature. The absorbance was then determined at $640 \mathrm{~nm}$. Regression equation was determined from blank and standard samples before ammonia- $\mathrm{N}$ was estimated in the samples.

\section{DNA extraction and quantification using qPCR}

Total genomic DNA from rumen content samples on day 0 , day 12 , and day 30 was extracted using QIAamp DNA Stool Mini Kit (Qiagen Inc., Valencia, CA, USA). The guideline on the protocol was provided by the manufacturer. The extracted DNA was stored at $-20{ }^{\circ} \mathrm{C}$ until subsequent procedures. Real-time PCR was used to determine the population of total bacteria, F. succinogens, $R$. albus, $R$. flavefaciens, methanogens, and protozoa. Species-specific PCR primers used to amplify partial 16S rDNA regions were chosen from literatures as presented in Table 5. Real-time PCR amplification and detection were performed using CFX 96 system (Bio-Rad, Hercules, CA, USA). The amplification reaction was conducted in a final volume of $25 \mu \mathrm{l}$ containing $12.5 \mu$ l Maxima SYBR Green qPCR Master Mix, $1 \mu \mathrm{l}$ species-specific PCR forward primer, $1 \mu \mathrm{l}$ species-specific PCR reverse primer, $8.5 \mu \mathrm{l}$ RNAse-free distilled water, and $2 \mu \mathrm{l}$ of DNA elution. The PCR conditions of all species were as follows: an initial denaturation $95{ }^{\circ} \mathrm{C}$ for $15 \mathrm{~s}$, followed by 39 cycles of denaturing of $15 \mathrm{~s}$ at $95{ }^{\circ} \mathrm{C}, 30 \mathrm{~s}$ at annealing temperature, and $20 \mathrm{~s}$ at $72{ }^{\circ} \mathrm{C}$ for an extension. The standards used in this study were prepared according to the protocol demonstrated by [53]. Briefly, DNA was extracted from a pure culture of microorganisms of interest to produce a high concentration of the target DNA using normal PCR.
Later, the products of the PCR were purified using MEGAquick-spin $^{\text {TM }}$ (Intron Biotechnology, Inc.) The concentrations of the products were then measured using a Nanodrop ND-1000 spectrophotometer. An online formula [54] was used to calculate the number of copies of a template DNA per ml of elution buffer. Finally, standard curves were constructed using a serial dilution of plasmid DNA of each microbial group.

\section{Determination of apparent digestibility}

Apparent digestibility of each nutrient was calculated by measuring the feed intake and feces excreted. The feed and fecal samples were analyzed for nutrient of interest using similar procedures in the previous section of chemical analysis of feed and fecal samples. The differences between the amounts of nutrient consumed and excreted in the fecal samples are the amount of nutrient digested and absorbed:

Apparent digestibility (\%)

$$
=\frac{\text { amount of nutrient consumed }-}{\text { amount of nutrient consumed }} \times 100
$$

\section{Statistical analysis}

The sample size calculation for this study was established using the Resource Equation Approach.

The data for rumen fermentation and rumen microbial population were statistically analyzed using repeated measures of general linear model (GLM) procedure of [19]. It was used to analyze the parameters as affected by dietary treatments, days of sampling, and treatment $x$ day of sampling interaction in the model. The Duncan multiple range test was used to further compare means at $P<0.05$. The parameters for digestibility were analyzed using a one-way analysis of variance (ANOVA) using the GLM procedure of [55]. Mean differences were determined using the Duncan multiple range test at $P<0.05$.

\begin{tabular}{|c|c|c|c|c|}
\hline \multirow[t]{2}{*}{ Microbes } & \multicolumn{2}{|l|}{ Primer } & \multirow{2}{*}{$\begin{array}{l}\text { Amplicon } \\
\text { (base } \\
\text { pairs) }\end{array}$} & \multirow[t]{2}{*}{ Ref } \\
\hline & Forward & Reverse & & \\
\hline General bacteria & 5'-CGGCAACGAGCGCAACCC-3' & 5'-CCATTGTAGCACGTGTGTAGCC-3' & 130 & {$[56,57]$} \\
\hline Fibrobacter succinogenes & 5'-GTTCGGAATTACTGGGCGTAAA-3' & 5'-CGCCTGCCCCTGAACTATC-3' & 121 & {$[56,57]$} \\
\hline Ruminococcus albus & 5'-CCC TAA AAG CAG TCT TAG TTC G-3' & 5'-CCT CCT TGC GGT TAG AAC A-3' & 175 & {$[58]$} \\
\hline Ruminococcus flavefaciens & 5'-CGAACGGAGATAATTTGAGTTACTTAGG-3' & 5'-CGGTCTCTGTATGTTATGAGGTATTACC-3' & 132 & {$[56,57]$} \\
\hline Methanogenic archea & 5'-TTCGGTGGATCDCARAGRGC-3' & 5'-GBARGTCGWAWCCGTAGAATCC-3' & 140 & [19] \\
\hline Protozoa & 5'-GCTTCGWTGGTAGTGTATT-3' & 5'-CTTGCCCTCYAATCGTWCT-3' & 223 & [19] \\
\hline
\end{tabular}

Table 5 The PCR primer used for quantification of rumen microorganism 


\section{Abbreviations}

CNT: Control; OL: Olive oil; PO: Palm oil; SF: Sunflower oil; VFA: Volatile fatty acids

\section{Acknowledgements}

We would like to thank the staff members of the Institute Tropical Agriculture Laboratory, Animal Science Department Laboratory and Goat Unit Ladang 2, Universiti Putra Malaysia for their assistance.

\section{Funding}

This research was funded by RUGS (9199720) awarded by Universiti Putra Malaysia. Nur Atikah I. was a recipient of MyBrain15 Scholarship from the Malaysia Ministry of Higher Education.

\section{Availability of data and materials}

Availability of data and materials used and analyzed during this study is available from the corresponding author on reasonable request.

\section{Authors' contributions}

Conceived and designed the experiment: MI, ARA, AAS. Provide supervision for animal health assessment during experiment: AAS, HY. Performed the experiment: NAI. Analyzed the data: NAI, MI, MFJ. Data interpretation and scientific discussion: NAl, ARA, AAS, MFJ, HY, NA. Contributed reagents/ materials: AAS, ARA, HY, NA. Writing the manuscript: NAI, AAS. All authors have read and approved the final manuscript.

\section{Ethics approval and consent to participate}

The study was conducted in compliance to the Animal Utilisation Protocol approved by the Institutional Animal Care and Use Committee (IACUC) (Approval No. R064/2016), Universiti Putra Malaysia. The sampling from experimented animals were strictly conducted under veterinary supervision.

\section{Consent for publication}

Not applicable.

\section{Competing interests}

The authors declare that they have no competing interests.

\section{Publisher's Note}

Springer Nature remains neutral with regard to jurisdictional claims in published maps and institutional affiliations.

\section{Author details \\ ${ }^{1}$ Institute of Tropical Agriculture, Universiti Putra Malaysia, UPM, 43400 Serdang, Selangor, Malaysia. ${ }^{2}$ Department of Animal Science, Faculty of Agriculture, Universiti Putra Malaysia, UPM, 43400 Serdang, Selangor, Malaysia.}

Received: 1 January 2018 Accepted: 25 October 2018

\section{Published online: 14 November 2018}

\section{References}

1. Mosoni P, Chaucheyras-Durand F, Béra-Maillet C, Forano E. Quantification by real-time PCR of cellulolytic bacteria in the rumen of sheep after supplementation of a forage diet with readily fermentable carbohydrates: effect of a yeast additive. J Appl Microbiol. 2007;103(6):2676-85.

2. Chanthakhoun V, Wanapat M, Kongmun P, Cherdthong A. Comparison of ruminal fermentation characteristics and microbial population in swamp buffalo and cattle. Livest Sci. 2012;143(2):172-6.

3. Ørskov ER. Protein nutrition in ruminants. (London) Ltd: Academic Press Inc; 1982.

4. Benchaar C, Romero-Pérez GA, Chouinard PY, Hassanat F, Eugene M, Petit $H V$, Côrtes C. Supplementation of increasing amounts of linseed oil to dairy cows fed total mixed rations: effects on digestion, ruminal fermentation characteristics, protozoal populations, and milk fatty acid composition. J Dairy Sci. 2012;95(8):4578-90.

5. Kadkhoday A, Riasi A, Alikhani M, Dehghan-Banadaky M, Kowsar R. Effects of fat sources and dietary C18: 2 to C18: 3 fatty acids ratio on growth performance, ruminal fermentation and some blood components of Holstein calves. Livest Sci. 2017;204:71-7.
6. Liu SJ, Bu DP, Wang JQ, Liu L, Liang S, Wei HY, Zhou LY, Li D, Loor JJ. Effect of incremental levels of fish oil supplementation on specific bacterial populations in bovine ruminal fluid. J Anim Physiol Anim Nutr. 2012;96(1):9-16.

7. Ivan M, Petit HV, Chiquette J, Wright AD. Rumen fermentation and microbial population in lactating dairy cows receiving diets containing oilseeds rich in C-18 fatty acids. Brit J Nutr. 2013;109(7):1211-8.

8. Anantasook N, Wanapat M, Cherdthong A, Gunun P. Effect of plants containing secondary compounds with palm oil on feed intake, digestibility, microbial protein synthesis and microbial population in dairy cows. AsianAustralas J Anim Sci. 2013;26(6):820-6.

9. Kongmun P, Wanapat M, Pakdee P, Navanukraw C, Yu Z. Manipulation of rumen fermentation and ecology of swamp buffalo by coconut oil and garlic powder supplementation. Livest Sci. 2011;135(1):84-92.

10. Mao HL, Wang JK, Zhou YY, Liu JX. Effects of addition of tea saponins and soybean oil on methane production, fermentation and microbial population in the rumen of growing lambs. Livest Sci. 2010;129(1):56-62.

11. Patra AK, Kamra DN, Agarwal N. Effect of plant extracts on in vitro methanogenesis, enzyme activities and fermentation of feed in rumen liquor of buffalo. Anim Feed Sci Technol. 2006;128(3):276-91.

12. Wales WJ, Kolver ES, Thorne PL, Egan AR. Diurnal variation in ruminal $\mathrm{pH}$ on the digestibility of highly digestible perennial ryegrass during continuous culture fermentation. J Dairy Sci. 2004:87(6):1864-71.

13. Ørskov E. Recent advances in understanding of microbial transformation in ruminants. Livest Prod Sci. 1994;39:53-60.

14. Messana JD, Berchielli TT, Arcuri PB, Reis RA, Canesin RC, Ribeiro AF, Fiorentini $G$, Fernandes JJ. Rumen fermentation and rumen microbes in Nellore steers receiving diets with different lipid contents. Rev Bras Zootecn. 2013:42(3):204-12.

15. Jenkins TC. Lipid metabolism in the rumen. J Dairy Sci. 1993;76(12):3851-63.

16. Adeyemi KD, Sazili AQ, Ebrahimi M, Samsudin AA, Alimon AR, Karim R, Karsani SA, Sabow AB. Effects of blend of canola oil and palm oil on nutrient intake and digestibility, growth performance, rumen fermentation and fatty acids in goats. Anim Sci J. 2016;87(9):1137-47.

17. Chelikani PK, Bell JA, Kennelly JJ. Effects of feeding or abomasal infusion of canola oil in Holstein cows 1. Nutrient digestion and milk composition. J Dairy Res. 2004;71:279-87.

18. Zinn RA. Influence of level and source of dietary fat on its comparative feeding value in finishing diets for feedlot steers: metabolism. J Anim Sci. 1989;67:1038-104.

19. Zhang CM, Guo YQ, Yuan ZP, Wu YM, Wang JK, Liu JX, Zhu WY. Effect of octadeca carbon fatty acids on microbial fermentation, methanogenesis and microbial flora in vitro. Anim Feed Sci Technol. 2008;146(3):259-69.

20. Harvatine KJ, Allen MS. Effects of fatty acid supplements on ruminal and total tract nutrient digestion in lactating dairy cows. J Dairy Sci. 2006;89(3): 1092-103.

21. Maia MR, Chaudhary LC, Figueres L, Wallace RJ. Metabolism of polyunsaturated fatty acids and their toxicity to the microflora of the rumen. Antonie Van Leeuwenhoek. 2007;91(4):303-14.

22. Tamminga S, Van Vuuren AM, Khattab HM, van Gils LG. Further studies on the effect of fat supplementation of concentrates fed to lactating dairy cows, 3: effect on rumen fermentation and site of digestion of dietary components. Neth J Agric Sci. 1983;31:249-58.

23. Hall KL, Goetsch AL, Landis KM, Forster LA Jr, Brake AC. Effects of a fat and ground maize supplement on feed intake and digestion by cattle consuming bermudagrass hay (Cynodon dactylon). Anim Feed Sci Technol. 1990;30(3-4):275-88.

24. Ørskov ER, MacLeod NA. The determination of the minimal nitrogen excretion in steers and dairy cows and its physiological and practical implications. Br J Nutr. 1982;47(3):625-36.

25. Wallace RJ, Broderick GA, Brammall ML. Microbial protein and peptide metabolism in rumen fluid from faunated and ciliate-free sheep. Br J Nutr. 1987:58(1):87-93.

26. Scollan ND, Dhanoa MS, Choi NJ, Maeng WJ, Enser M, Wood JD. Biohydrogenation and digestion of long chain fatty acids in steers fed on different sources of lipid. J Agric Sci. 2001;136(3):345-55.

27. Tesfa AT. Effects of rape-seed oil supplementation on digestion, microbial protein synthesis and duodenal microbial amino acid composition in ruminants. Anim Feed Sci Technol. 1993;41(4):313-28.

28. Kowalczyk J, Orskov ER, Robinson JJ, Stewart CS. Effect of fat supplementation on voluntary food intake and rumen metabolism in sheep. Brit. J. Nutr. 1977;37:251-7. 
29. Ikwuegbu OA, Sutton JD. The effect of varying amount of linseed oil supplementation on rumen metabolism in sheep. Brit J Nutr. 1982;48: 365-75.

30. Szumacher-Strabel M, Cieślak A, Nowakowska A. Effect of oils rich in linoleic acid on in vitro rumen fermentation parameters of sheep, goats and dairy cows. J Anim Feed Sci. 2009;18(3):440-52.

31. Shingfield KJ, Chilliard Y, Toivonen V, Kairenius P, Givens DI. Trans fatty acids and bioactive lipids in ruminant milk. In: Bosze $Z$, editor. Bioactive Components of Milk. New York: Springer; 2008. p. 3-65.

32. Ebrahimi M, Rajion MA, Adeyemi KD, Jafari S, Jahromi MF, Oskoueian E, Meng GY, Ghaffari MH. Dietary n-6: n-3 fatty acid ratios alter rumen fermentation parameters and microbial populations in goats. J Agr Food Chem. 2017;65(4):737-44

33. Yabuuchi Y, Matsushita Y, Otsuka H, Fukamachi K, Kobayashi Y. Effects of supplemental lauric acid-rich oils in high-grain diet on in vitro rumen fermentation. Anim Sci J. 2006;77(3):300-7.

34. Adeyemi KD, Ahmed MA, Jotham S, Roslan NA, Jahromi MF, Samsudin AA Sazili AQ. Rumen microbial community and nitrogen metabolism in goats fed blend of palm oil and canola oil. Ital J Anim Sci. 2016;15(4):666-72.

35. Finlay BJ, Esteban G, Clarke KJ, Williams AG, Embley TM, Hirt RP. Some rumen ciliates have endosymbiotic methanogens. FEMS Microbiol Lett. 1994;117(2):157-61.

36. Sutton JD, Knight R, McAllan AB, Smith RH. Digestion and synthesis in the rumen of sheep given diets supplemented with free and protected oils. $\mathrm{Br}$ J Nutr. 1983 May;49(3):419-32.

37. Ruiz R, Albrecht GL, Tedeschi LO, Jarvis G, Russell JB, Fox DG. Effect of monensin on the performance and nitrogen utilization of lactating dairy cows consuming fresh forage. J Dairy Sci. 2001;84(7):1717-27.

38. Manso T, Castro T, Mantecón AR, Jimeno V. Effects of palm oil and calcium soaps of palm oil fatty acids in fattening diets on digestibility, performance and chemical body composition of lambs. Anim Feed Sci Technol. 2006; 127(3):175-86.

39. Bauchart D, Legay-Carmier F, Doreau M. Ruminal hydrolysis of dietary triglycerides in dairy cows fed lipid-supplemented diets. Reprod Nutr Dev. 1990;30(Suppl2):187s-187s.

40. Gerson T, John A, King ASD. The effects of dietary starch and fibre on the in vitro rates of lipolysis and hydrogenation by sheep rumen digesta. J Agric Sci. 1985:105(1):27-30.

41. Oldick BS, Firkins JL. Effects of degree of fat saturation on fibre digestion and microbial protein synthesis when diets are fed twelve times daily. J Anim Sci. 2000;78(9):2412-20.

42. Palmquist DL. The role of dietary fats in efficiency of ruminants. J Nutr. 1994; 124(suppl_8):13775-82S.

43. Bhatt RS, Soren NM, Tripathi MK, Karim SA. Effects of different levels of coconut oil supplementation on performance, digestibility, rumen fermentation and carcass traits of Malpura lambs. Anim Feed Sci Technol. 2011;164(1-2):29-37.

44. Hoover WH, Miller TK, Stokes SR, Thayne WV. Effects of fish meals on rumen bacterial fermentation in continuous Culture1. J Dairy Sci. 1989; 72(11):2991-8.

45. Choi BR, Palmquist DL, Allen MS. Cholecystokinin mediates depression of feed intake in dairy cattle fed high fat diets $s$ 1. Domest Anim Endocrinol. 2000;19(3):159-75.

46. Piantoni P, Lock AL, Allen MS. Palmitic acid increased yields of milk and milk fat and nutrient digestibility across production level of lactating cows. J Dairy Sci. 2013;96(11):7143-54.

47. NRC (National Research Council). Nutrient requirements of small ruminant. 6th ed. Washington: National Academy Press; 2007.

48. AOAC (Association of Official Analytical Chemists). Official methods of analysis. 15th ed. Washington: Association of Analytical Chemists; 1990.

49. Van Soest PV, Robertson JB, Lewis BA. Methods for dietary fibre, neutral detergent fibre, and nonstarch polysaccharides in relation to animal nutrition. J Dairy Sci. 1991;74(10):3583-97.

50. Malaysian Standard M.S. 1500. Halal food - production, preparation, handling and storage - general guidelines (second revision). Kuala Lumpur: Department of Standards Malaysia; 2009.

51. Cottyn BG, Boucque CV. Rapid method for the gas-chromatographic determination of volatile fatty acids in rumen fluid. J of Agricult and Food Chem. 1968;16(1):105-7.

52. Parsons TR, Maita Y, Lalli CM. A manual of chemical and biological methods for seawater analysis. Oxford: Pergamon Press; 1984.
53. Navidshad B, Liang JB, Jahromi MF. Correlation coefficients between different method of expressing bacterial quantification using real time PCR. Int J Mol Sci. 2012;13(2):2119-32.

54. Staroscik A. Calculator for determining the number of copies of a template. URI Genomics \& Sequencing Center. 2004. https://cels.uri.edu/gsc/cndna. html. Accessed 10 Jan 2014.

55. SAS Institute Inc. SAS User's Guide, Version 9.1. 2nd ed. Cary: SAS Institute Inc; 2003.

56. Samsudin AA, Wright AD, Al Jassim R. The effect of fibre source on the numbers of some fibre-degrading bacteria of Arabian camel's (Camelus dromedaries) foregut origin. Trop Anim Health and Prod. 2014;46(7):1161-6.

57. Denman SE, McSweeney CS. Development of a real-time PCR assay for monitoring anaerobic fungal and cellulolytic bacterial populations within the rumen. FEMS Microbiol Ecol. 2006;58(3):572-82.

58. Koike S, Kobayashi Y. Development and use of competitive PCR assays for the rumen cellulolytic bacteria: Fibrobacter succinogenes, Ruminococcus albus and Ruminococcus flavefaciens. FEMS Microbiol Lett. 2001;204(2):361-6.

\section{Ready to submit your research? Choose BMC and benefit from:}

- fast, convenient online submission

- thorough peer review by experienced researchers in your field

- rapid publication on acceptance

- support for research data, including large and complex data types

- gold Open Access which fosters wider collaboration and increased citations

- maximum visibility for your research: over $100 \mathrm{M}$ website views per year

At $\mathrm{BMC}$, research is always in progress.

Learn more biomedcentral.com/submissions 